\title{
BARONESS BURDETT-COUTTS' GARDEN PARTY: THE INTERNATIONAL MEDICAL CONGRESS, LONDON, 1881
}

\author{
by
}

\begin{abstract}
ALEX SAKULA*
JUST OVER one hundred years ago, in August 1881, there took place in London the 7th International Medical Congress, arguably the greatest and most historic medical congress ever held. As part of the social programme, Baroness Burdett-Coutts held a garden party at her Highgate home, Holly Lodge, at which she received the most eminent British and foreign participants in the Congress. This special occasion was recorded in a large group-portrait painting, which now hangs in the Wellcome Institute for the History of Medicine, London (Fig. 2). Little has been previously known about this interesting painting and there does not appear to exist any key which would facilitate identification of the ninety-four persons portrayed.

This paper describes how the painting came to be executed for Baroness BurdettCoutts, tells the story of the Baroness, the artist, and the provenance of the painting, and attempts to identify as many as possible of the Congress participants portrayed.
\end{abstract}

\section{THE CONGRESS}

There had been previous International Medical Congresses: the first in 1867 in Paris, the second in 1869 in Florence, the third in 1873 in Vienna, the fourth in 1875 in Brussels, the fifth in 1877 in Geneva, and the sixth in 1879 in Amsterdam. However, the seventh in 1881 in London was to prove to be the largest and most successful ever. The Congress lasted one week, Tuesday 2 August to Tuesday 9 August. Under the patronage of Queen Victoria, the Congress was opened in St. James' Hall, Piccadilly, in the presence of H.R.H. the Prince of Wales (the future King Edward VII), who was accompanied by his German cousin, His Imperial and Royal Highness the Crown Prince of Prussia (the future Frederick III), whose cancer of the larynx was to cause a medical furore seven years later. The organizing genius of the Congress was Sir William MacCormack, and there were 3,181 registered participants. As the British Medical Journal reported: "The number of medical men who have poured into the city from all parts of the world has no precedent in medical history, nor are they undistinguished persons, but from every country may be recognised names which can be counted as among the most highly representative. Not a few are chieftains of science. Among the members of the Congress ... may be recognised men bearing names famous throughout Europe". ${ }^{1}$ These included, among others, such British

*Alex Sakula, M.D., F.R.C.P., D.H.M.S.A., Senior Physician, Redhill General Hospital, Surrey.

1 Br. med. J., 1881, ii: 234. 


\section{Alex Sakula}

personalities as Sir James Paget (who was elected President of the Congress), Lord Lister, Sir Jonathan Hutchinson, Sir Samuel Wilks, Sir William Bowman, Sir William Gull, and Professors Richard Owen and Thomas Huxley; while the distinguished European names included Rudolf Virchow, Louis Pasteur, Robert Koch, Jean Martin Charcot, Richard von Volkmann, Bernard von Langenbeck, and Frederick von Esmarch; and from North America came General John Shaw Billings, Professors Austin Flint and Palmer Howard, and Sir William Osler. Truly a galaxy of medical super-stars!

General meetings were addressed by Virchow (on 'The value of physiological experiments', in which he spoke against antivivisection); by Volkmann (on 'Modern surgery'); by Huxley (on 'The connection of the biological sciences with medicine'); and by Pasteur (on 'Vaccination in relation to chicken cholera and splenic fever'). Maurice Raynaud had died shortly before the Congress, and his paper on 'Scepticism in medicine, past and present' was read by a friend. General J. S. Billings delivered an address 'On medical literature' in which he succintly expressed his credo for the preparation of a medical article: "The four rules ... (1) Have something to say; (2) Say it; (3) Stop as soon as you have said it; and (4) Give the paper a proper title"!

In addition to these addresses to the general assembly, fifteen sections met at Burlington House and elsewhere, and in all there were 410 communications and 858 speakers. Professor Charcot spoke on 'Arthropathic affections of locomotor ataxy', William Osler on 'Ulcerative endocarditis', Sir John Simon on 'The public health'; but the greatest impression was made by Louis Pasteur when he spoke on immunization against anthrax. Koch's demonstration of his new bacteriological techniques, using solid media, also drew universal acclamation, and even Pasteur was forced to acknowledge: "C'est un grand progrès". The Congress proved to be a landmark in the general acceptance of the role of the new science of bacteriology in medicine, surgery, and public health. Antivivisection was at that time a topic of public debate, so it was not surprising that the Congress adopted a resolution supporting the use of vivisection in animal experiments, but with humanitarian control.

English, French, and German were the official languages of the Congress, and the transactions were published by MacCormack later in $1881 .^{2}$

\section{FESTIVITIES AT THE CONGRESS}

In a letter to his wife, written before the Congress, Sir Jonathan Hutchinson expressed the following sentiments:

15 Cavendish Square, $\mathbf{W}$. March 24, 1881

... According to my feeling, these Congresses are great religious gatherings, in which prayer is offered for the progress of knowledge and the well-being of men. A great effort is also made in the way of social intercourse, to promote the general sentiment of good brotherly feeling, and to make people feel that the Maker has indeed made us all of one blood.

Here comes the excuse for dinners, for friendly joke and conversation, and for social life in general, as distinct from the more serious efforts in positive work. ${ }^{3}$

${ }^{2}$ Sir William MacCormack (editor), Transactions of the International Medical Congress, 7 th Session, 4 vols., London, J. W. Kolckmann, 1881 .

${ }^{3}$ Herbert Hutchinson, Jonathan Hutchinson: life and letters, London, Heinemann, 1946, pp. 149-150. 


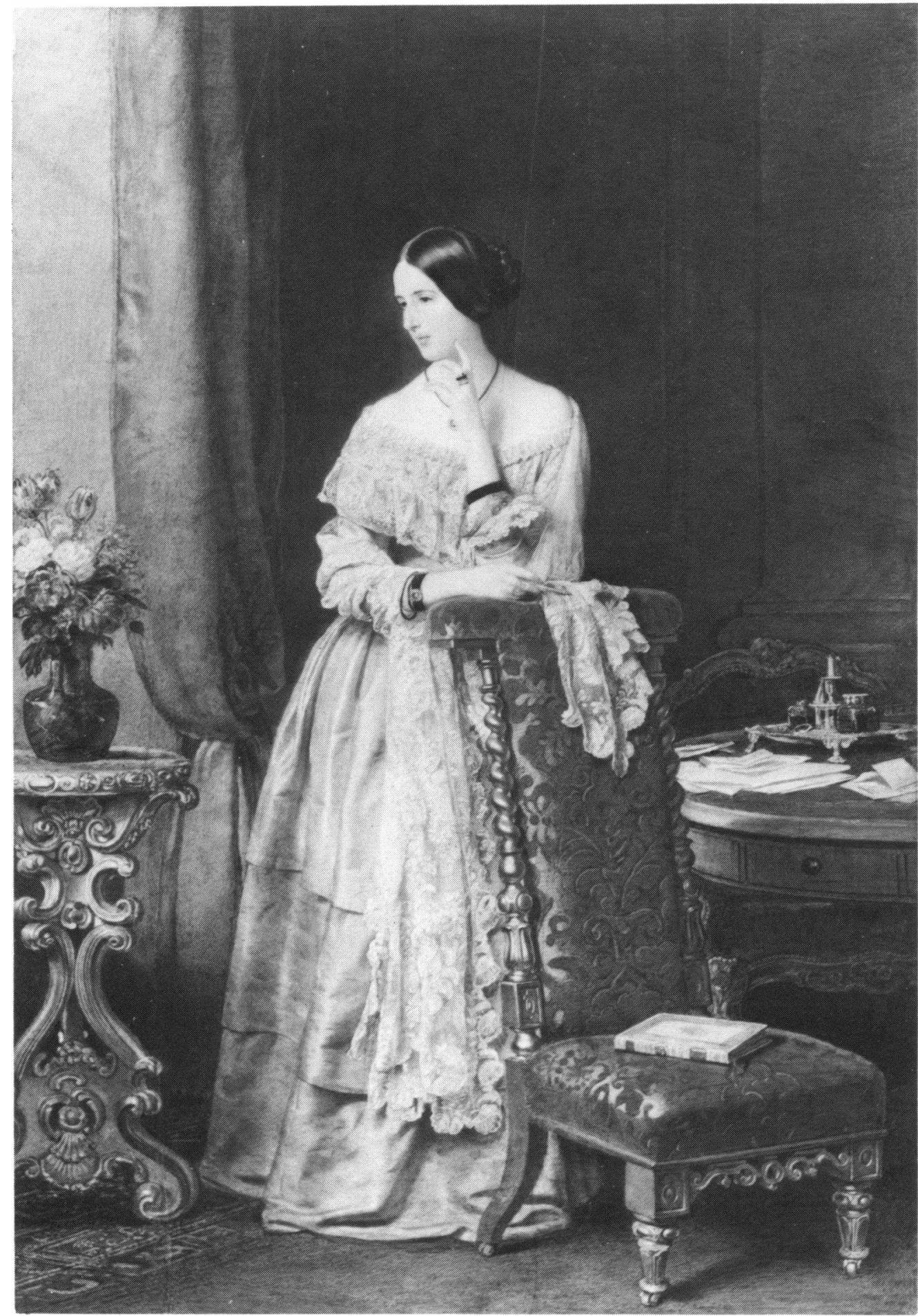
Figure 1 Baroness Burdett-Couts, 1858. Watercolour upon ivory by W. C. Rose. (By courtesy of the
Ooffional Portrail Gallery.) Published online by Cambridge University Press 


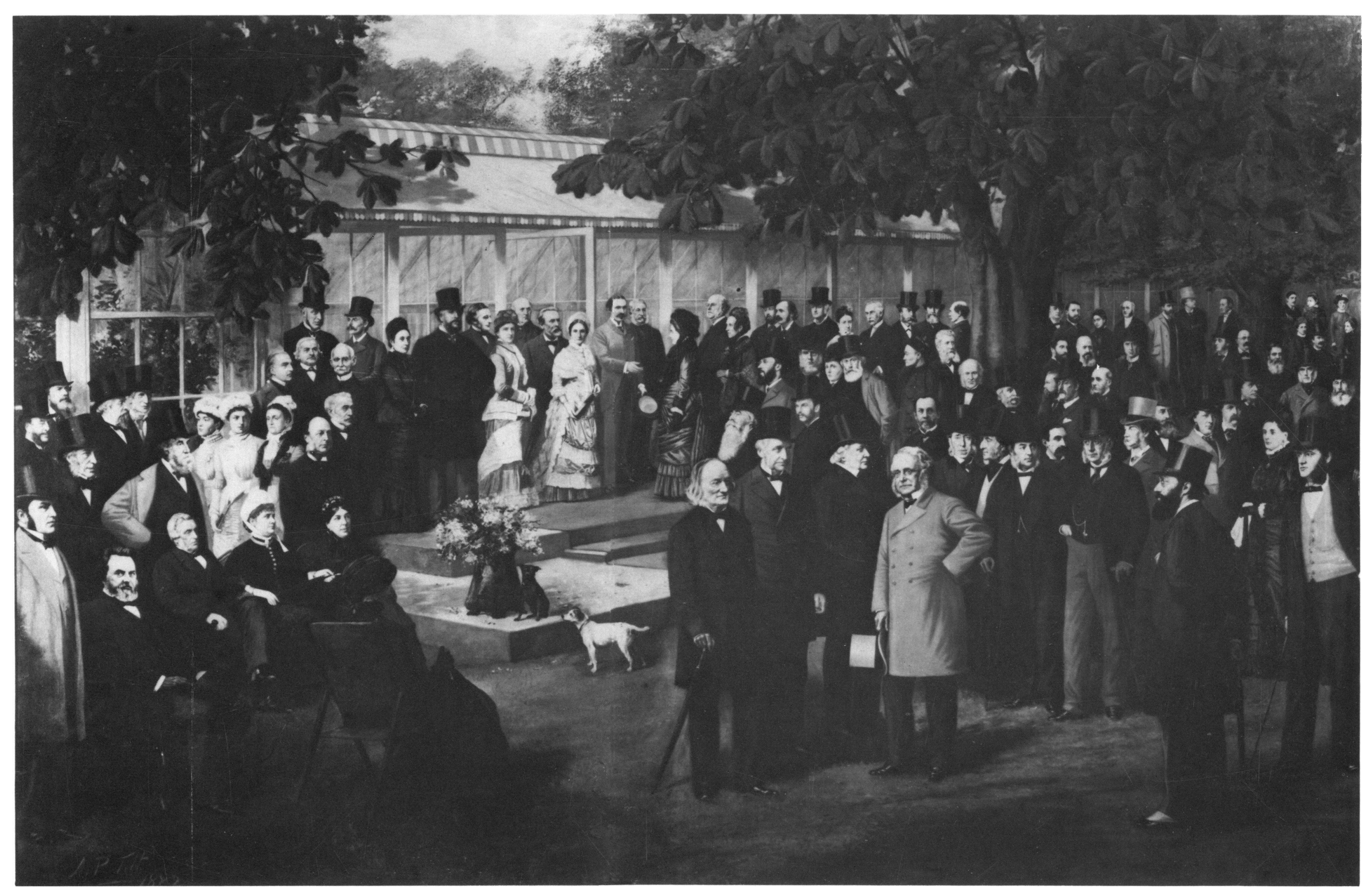




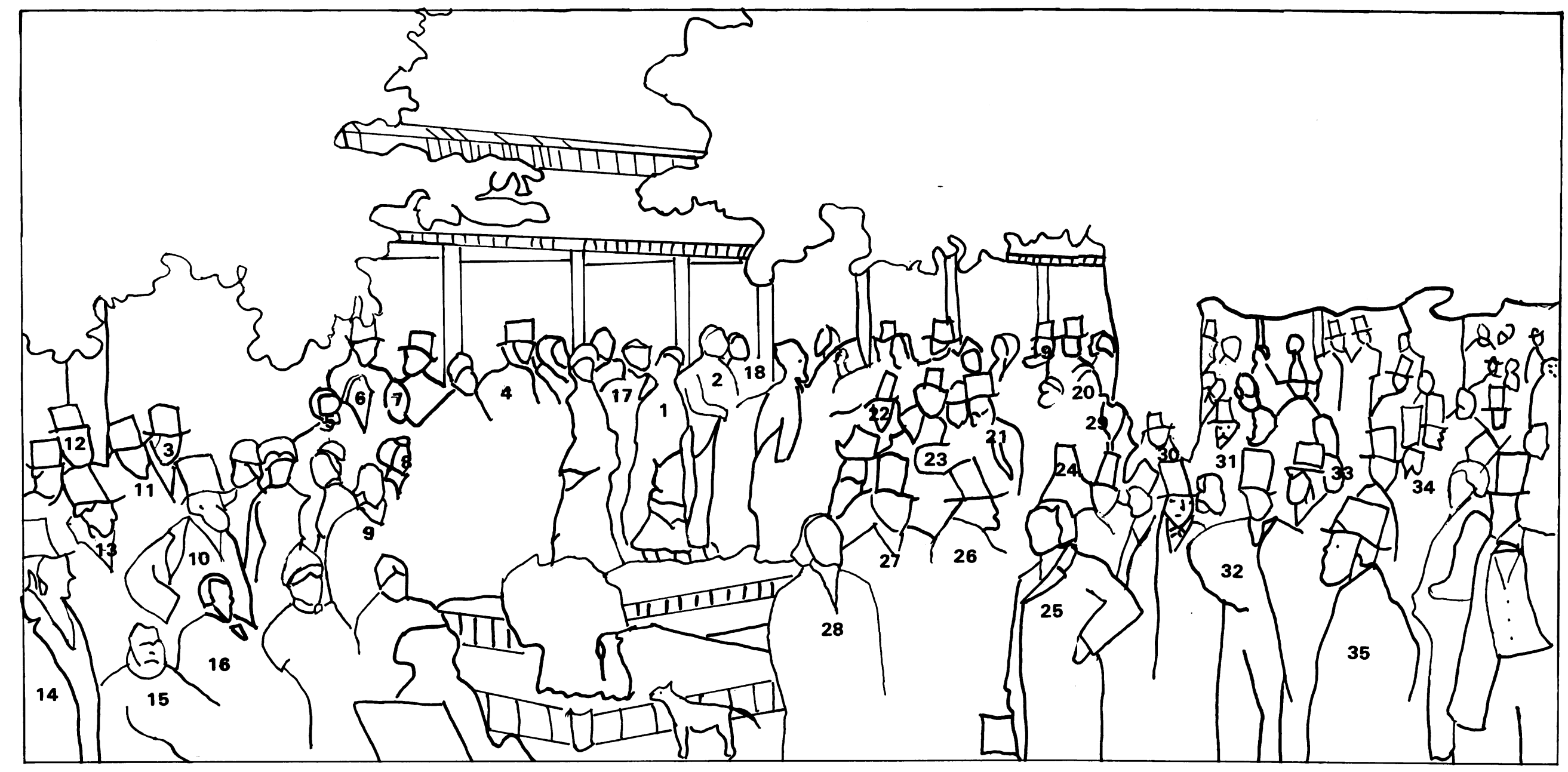

Figure 3. Key to Figure 2.

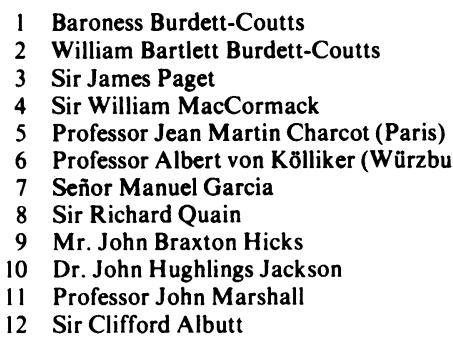

13 Sir James Risdon-Bennett

14 Professor John Wood

Professor Frans Cornelius Donders (Utrecht)

17 Sir William Bowman

18 Professor Douglas Argyll-Robertson (Edinburgh)

19 Professor Richard von Volkmann (Halle)

20 Professor Frederick von Esmarch (Kiel)

21 Sir Samuel Wilks

22 Sir Jonathan Hutchinson

24 Professor Bernard von Langenteck
1809-1891 72 $\begin{array}{ll}1825-1891 & 56 \\ 1818-1889 & 63\end{array}$ $\begin{array}{ll}1818-1889 & 63 \\ 1816-1892 & 65\end{array}$ $1846-1912$ $1837-1909$ $1830-1889 \quad 51$ 1823-1908 $1824-1911$ $1828-19113$ $1822-1895 \quad 59$

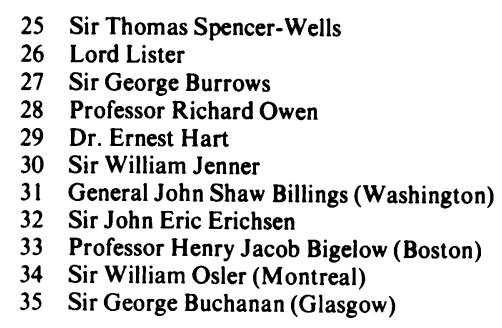
$\begin{array}{ll}1818-1897 & 63 \\ 1827-1912 & 54\end{array}$ $1801-1887 \quad 80$ $1835-1898 \quad 46$ $1815-1898-66$ $1838-1913$ $1818-1896$

$1818-1890$
$1849-1919$ $1831-1893 \quad 50$ 


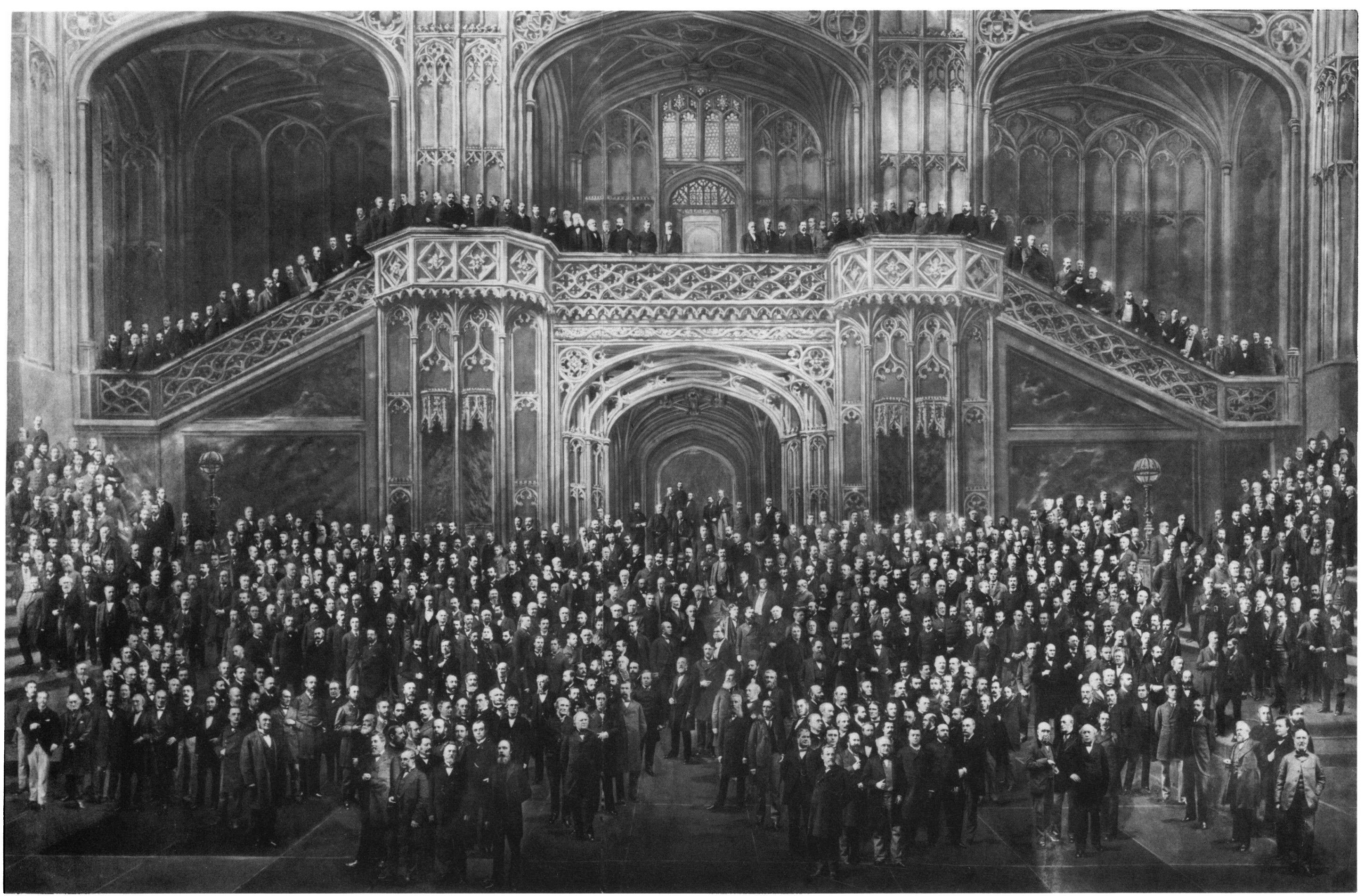

Figure 4. Members of the International Medical Congress, London, 1881. Photograph by H. R. Barraud (A key to this group photograph is available from the Assistant Editor, Medical History, Wellcome Institute, 183 Euston Road, London NW1 2BP.) 
A vast programme was arranged for the participants and their spouses. There was an opening reception at the Royal College of Physicians, conversaziones at the Royal College of Surgeons and South Kensington Museum, a banquet by the Lord Mayor at the Mansion House, a dinner at the Worshipful Society of Apothecaries, a soirée at the Albert Hall, and many other excursions. Private receptions and garden parties took place at the homes of Sir James Paget in Hanover Square, Sir Thomas SpencerWells in Hampstead, and Dr. Langdon Down in Hampton. Special services were held at Westminster Abbey and St. Paul's. The Congress ended with a visit to the Crystal Palace for a dinner, followed by a display of fountains and fireworks, with large fireportraits of Paget, Charcot, and von Langenbeck !4

It was in the context of such varied social activities, truly an embarras de richesse, that the garden party took place on Monday afternoon, 8 August 1881, at Holly Lodge, Highgate, the home of Baroness Burdett-Coutts, who received the most important members of the Congress.

\section{BARONESS BURDETT-COUTTS}

Baroness Burdett-Coutts (Fig. 1), was born on 21 April 1814, as Angela Georgina Burdett, daughter of the politician, Sir Francis Burdett, Bart. (1770-1844), who was Member of Parliament for Westminster. Her mother was Sophia Coutts (1775-1844), the daughter of Thomas Coutts, M.P. (1735-1822), banker to George III and founder of the bank, Coutts \& Co. In 1837, aged twenty-three, Angela inherited from the Duchess of St. Albans (second wife of Thomas Coutts) all her property and share in the bank, Coutts \& Co., and she became overnight the richest heiress in England and came to be described as "made of gold". She added Coutts to her name, and was thereafter known as Burdett-Coutts although she herself preferred to be called plain Miss Coutts.

At her town house, 1 Stratton Street, Piccadilly, she entertained lavishly, and became one of the great society hostesses of the Victorian era. She was an intimate of Queen Victoria and of numerous celebrities of the time: leading politicians, such as the Duke of Wellington, Sir Robert Peel, Disraeli, and Gladstone; and the great men of literature and the stage, such as Sir Walter Scott and Sir Henry Irving. Charles Dickens was a special friend and adviser - he said of her: "She was the noblest spirit we can ever know". She devoted herself and her riches to a wide variety of social causes, both at home and abroad - ecclesiastical endowments, missionary ventures, the welfare of children and animals. When she travelled, she was greeted with the cry: "God bless the Queen of the Poor". For these philanthropic activities, she was in 1871 raised to the peerage, the first woman to be so elevated in recognition of her own achievements, and she adopted the title Baroness Burdett-Coutts of Highgate. In 1872, she received the Freedom of the City of London, again the first woman to have this honour bestowed. Edward VII said of her: she was ". . . after my mother, the most remarkable woman in the Kingdom".

She had, when younger, been in love with the Duke of Wellington and even

4 Br. med. J., 1881, ii: 303-304.

'Edna Healey, Lady unknown: the life of Angela Burdett-Coutts, London, Sidgwick \& Jackson, 1978. 


\section{Alex Sakula}

proposed to him (he was aged seventy-eight, and she thirty-three!) but they did not marry. She remained a spinster until 1881, when, on 12 February, she surprised Victorian society by marrying one of her assistants in philanthropic work, William Lehman Ashmead Bartlett (1851-1921). He was American-born but of English extraction; she had known him since his boyhood and had financed his education. At the time of the marriage she was aged sixty-seven, he was thirty! Queen Victoria was not amused and commented: "The woman must be crazy!", and when the Baroness and her spouse were presented to her on 4 May 1881, she wrote in her journal: "That poor foolish old woman, Lady Burdett-Coutts, was presented on her marriage with Mr. Bartlett, 40 years younger than herself. She looked like his grandmother, and was decked out with jewels - not edifying". Nevertheless, the Baroness remained happy with her young husband for the next twenty-five years, until she died on 30 December 1906, aged ninety-two. She was buried in Westminster Abbey, her tomb situated below the memorial to the Earl of Shaftesbury. ${ }^{6,7,8}$

Her husband, who had by Royal Licence assumed the name Bartlett-BurdettCoutts, was Conservative M.P. for Westminster from 1885, and lived on until 1921.

\section{HOLLY LODGE, HIGHGATE}

Holly Lodge was new in 1809 , when it was leased to the actress Harriet Mellon (1777-1837), who was first married to Thomas Coutts, and then to the Duke of St. Albans. It was on the death of the duke in 1849, that Angela Burdett-Coutts moved into Holly Lodge, which she came to love dearly as her summer house. The house was a two-storey villa in Regency style, with some extensions, but the twenty-one-acre garden was beautifully laid out, and from its highest point there was a spectacular view down across London and beyond to the Surrey Hills. It was here that she developed her model farm (she was keen on goat-breeding!) and garden village. The house has now been demolished, and a modern estate - Holly Lodge Gardens occupies the site, but some of the original garden and gates are preserved and may be visited. ${ }^{9,10}$

\section{THE GARDEN PARTY}

The summer of 1881 had been an especially hot one, the temperature on one day in July having reached the record figure of $97^{\circ} \mathrm{F}\left(36^{\circ} \mathrm{C}\right)$. The British Medical Journal reported: "Notwithstanding the heavy rain which fell during the afternoon, a large number of visitors attended the garden party given by Baroness Burdett-Coutts at her residence at Highgate". "The president, officers, and important members of the Congress - British and foreign - were invited and were received by the Baroness and her recently married young husband.

The Congress programme on that Monday, 8 August, was certainly a very crowded

DNB.

'Clara Burdett Patterson, Angela Burdett-Coutts and the Victorians, London, John Murray, 1953.

- Diana Orton, Made of gold, London, Hamish Hamilton, 1980.

- Victoria history of the County of Middlesex, 1980, vol. 6, pp. 128-129.

${ }^{10} \mathrm{I}$. Norrie (editor), The Heathside book of Hampstead and Highgate, London, High Hill Books, 1962, pp. $112-114$.

"Br. med. J., 1881, ii: 303. 
one. The Sections had met in the morning 10 a.m. to 1 p.m. At 11 a.m., many members of the Congress had embarked on a Thames boat-trip. At 4 p.m., Professor Volkmann was billed to address a general meeting on 'Modern surgery' in the theatre of the University of London; and later that afternoon, Pasteur delivered his important address on 'Vaccination in relation to chicken cholera and splenic fever (anthrax)'. At 6.30 p.m., many participants were to attend a dinner at the Worshipful Society of Apothecaries, Blackfriars; while later still, at 9 p.m., there was to be a soiree at the Albert Hall, and a visit to the medical exhibition at South Kensington had also been arranged.

No doubt the Congress members could be selective as to how many of these professional and social activities they wished to attend! Certainly, their fatigue would have been compounded if they had journeyed to Folkestone on the previous Saturday, 6 August, to attend the unveiling of the statue of William Harvey, with an address by Professor Richard Owen. ${ }^{12.13}$ On the following day, Tuesday 9 August, there would be the concluding session of the Congress, and many would need to travel to Ryde, Isle of Wight, where the 47th Annual Meeting of the British Medical Association was due to open on that day also. ${ }^{14}$

\section{THE PICTURE: ITS PAINTER AND PROVENANCE}

On 10 December 1881, the British Medical Journal carried the following announcement: "Messrs. Dickinson of Bond Street are painting a large group-picture of the garden party given by the Baroness Burdett-Coutts to the International Medical Congress in August last. The picture will contain about 100 of the leading visitors and presidents of sections. No doubt it will be engraved when completed."1s

Dickinson Bros. \& Foster of 114 New Bond Street, W.1., were classified in the Post Office Directory 1881 as "Portrait Painters". The group-portrait of the garden party was commissioned by Dickinson \& Foster on behalf of Baroness Burdett-Coutts, who wished to have a pictorial record of the historic event.

The artist was Archibald Preston Tilt (1854-?1890). The painting is signed in the bottom left-hand corner: "A. P. Tilt, 1882", the signature being obviously in the same hand as the signature "Archibald P. Tilt" which is found on a print after a painted portrait of the jockey Fred Archer, exhibited at the Royal Academy in 1887. The same painter had also exhibited paintings entitled "O Solitude ..." at the Royal Academy in 1877, ${ }^{16}$ and "Dutch Fishing Girl" at the Royal Society of British Artists, Suffolk Street, in 1875. ${ }^{17}$

Unfortunately, not a great deal is known about the artist. Information obtained from descendants of the Tilt family alive today has revealed that he was one of six brothers, all artists, three of whom bore the name "A. P. Tilt", the A standing for Alfred (b. 1851), Arthur (b. 1853), and Archibald (b. 1854) respectively. All died

\footnotetext{
12 Ibid., 304.

${ }^{13}$ Alex Sakula, [editorial], History of Medicine, 1980, 8, no. 4: 3-4.

14 Br. med.J., 1881, ii: 290.

1s Ibid., 945.

16 Algernon Groves, The Royal Academy of Arts: the complete dictionary of contributors and their work, from its foundation in 1769 to 1904, London, George \& Bell, 1905-6.

17 Jane Johnson, Works exhibited at Royal Society of British Artists 1824-1893, Woodbridge, Antique Collectors' Club Research Project, 1975.
} 


\section{Alex Sakula}

relatively young from tuberculosis. ${ }^{18}$ Their father was the successful portrait-painter, Frederick Arnaud Clarke Tilt (1823-1869) of Walton-on-the-Hill, Surrey, who is chiefly remembered for his miniature portrait of Queen Victoria (1869), painted at her command, and presented by her to the great American philanthropist, George Peabody (1795-1869). This painting now hangs in the Peabody Institute, near Boston, Massachusetts. ${ }^{19}$

The painting of the garden party was in the possession of Baroness Burdett-Coutts until her death in 1906, when it passed to her husband, William Ashmead BartlettBurdett-Coutts. Following his death in 1921, the Burdett-Coutts collection came up for sale at Christie's on 4 May 1922. The catalogue stated: "Sold by order of Executor of Rt. Hon. W. Burdett-Coutts, M.P. Deceased, late of 1 Stratton Street, W. \& Holly Lodge, Highgate". The painting of the garden party (Lot 246) was purchased by one "Moore" ( $\mathrm{sic}$ ) for the sum of $£ 55 s \mathrm{~d}$. Seven weeks later, on 28 June 1922, the painting was for sale again, this time at Fosters, 54 Pall Mall, W. (Lot 179) and was purchased by the Wellcome Institute for $£ 2100$ s $0 d$ ! Its accession was registered on 22 October 1928, and it is now on display in the Wellcome Institute. It has not been possible to locate any engravings of this painting, and probably none was made.

Until the present time, only a few of the more famous medical figures have been recognized, the greater number remaining un-named. No official or original key to the group-portrait exists. In the present study, an intensive search has failed to discover any list of those portrayed. ${ }^{20}$ But the list of the Congress members, and comparison with contemporary portraits and photographs have enabled many more faces to be identified. In particular, two other collections of photographs taken during the Congress have proved helpful.

The first is a series of photographs, of carte-de-visite size, of eminent members of the Congress taken by G. Jerrard, arranged in a large album and sold by Claudet's Photographic Studio, 107 Regent Street, W.1. ${ }^{21}$ Prints of Jerrard's photographs are in the libraries of the Royal College of Physicians of London and the Wellcome Institute.

The second is a remarkable composite photograph by Mr. Herbert R. Barraud of 96 Gloucester Place, W.1., who arranged 684 members of the Congress against a neoGothic background, probably the interior of St. James' Hall, Piccadilly. This photograph, together with a key, was published by Baillière, Tindall \& Cox, $20 \mathrm{King}$ William Street, W.C.1., in two sizes: $47^{\prime \prime} \times 30^{\prime \prime}$ or $29^{\prime \prime} \times 20^{\prime \prime}{ }^{22}$ (Fig. 4).

There can be little doubt that the artist, Archibald P. Tilt, made use of such photographs as a basis for his group-portrait painting.

18 Personal communication.

19 Christopher Wood, Dictionary of Victorian Painters, 2nd ed., Woodbridge, Antique Collectors Club, 1978, p. 474.

${ }^{20}$ The following were consulted for contemporary comment, but with negative results: The Times, Hampstead and Highgate Express, Illustrated London News, Graphic, Art Journal, Magazine of Art, Athenaeum; Burdett-Coutts papers; British Library, Osborne Papers (Add. MSS 46402-08); Royal College of Physicians Library; National Portrait Gallery; Victoria and Albert Museum Library; Westminster Public Library (Fine Arts Department); Lambeth Palace Library; Highgate Literary and Scientific Institute; Camden Local History Library.

${ }^{21}$ Br. med. J., 1881, ii: 435.

${ }^{22}$ Lancet, 1882, i: 538. 


\section{Baroness Burdett-Coutts' garden party, 1881}

\section{DESCRIPTION OF THE PAINTING}

The painting, in oils, is on a large canvas $(200 \mathrm{~cm} . \times 135 \mathrm{~cm}$.). The setting is the garden of Holly Lodge, Highgate. Baroness Burdett-Coutts and her husband stand on the steps outside the conservatory, on the east side of the house. The main body of the guests are grouped under the large horse-chestnut tree. Considering that this was a hot August afternoon, all appear to be over-warmly dressed - etiquette, no doubt, demanded morning dress and top hats. The torrential rain reported that day no doubt accounts for some people wearing outer coats and carrying umbrellas.

Apart from the host and hostess, ninety-two persons are portrayed in the painting (Figs. 2 and 3). These include eighteen female figures, probably wives, although the two seated ladies on the left may well be senior members of the nursing profession. It is of interest that Sir James Paget, President of the Congress, has placed himself modestly on the extreme left. Sir William MacCormack, the Honorary Secretary of the Congress, however, stands prominently beside the Baroness. The group of three to the left of MacCormack are Professor J. M. Charcot, Professor Albert von Kölliker, and Señor Manuel Garcia. The impressive, bearded John Hughlings Jackson stands in front of Sir James Paget, and seated in front of him are Sir William Bowman and Professor Donders (who had been President of the previous International Medical Congress in 1879 in Amsterdam). In the rear row, centre, stands Professor Douglas Argyll-Robertson, and (nearer the tree) Professor Richard von Volkmann. The row of faces below them includes (from the left) Sir Jonathan Hutchinson, Sir Samuel Wilks, and (near the tree) the imposing white-bearded Professor Frederick von Esmarch. Staring out from the centre of the painting is, unmistakably, Professor Louis Pasteur. The prominent group of four in the centre foreground are (from the left) Sir Richard Owen, Sir George Burrows, Lord Lister, and Sir Thomas Spencer-Wells. At the foot of the tree stand Ernest Hart (famous editor of the British Medical Journal), Sir William Jenner, and General J. S. Billings. The prominent bearded figure in the foreground right is Sir George Buchanan. To the left of him stands Sir John Eric Erichsen, above whom is Henry Jacob Bigelow, to whose left is the pale, moustached face of Sir William Osler.

Only thirty-six of the seventy-four male figures have so far been identified with certainty. The portraits are very well executed, and the artist has arranged the large number of figures very skilfully. The dog (one of the Baroness's favourite pets) in the centre provides a charming distraction from the otherwise sombre gathering of overdressed medical men.

Finally, two special mysteries remain unsolved. Who is the lady seated on a chair in the foreground, with her back to the viewer? And who is the Chinese figure in the centre of the painting?

\section{SUMMARY}

After 100 years, the medico-historical significance of the 7th International Medical Congress, held in London in 1881, was probably the coming together of so many of the pioneers of medical bacteriology including Pasteur, Koch, and Lister - marking a turning-point in the general appreciation of the importance of the science of bacteriology in medicine, surgery, and public health. The most eminent members of the Congress were invited to a garden party on 8 August 1881 , given by the great Victorian philanthropist, Baroness Burdett-Coutts, at her home, Holly Lodge, Highgate, and the occasion was put on record in a splendid group-portrait painting by A. P. Tilt. 


\section{Alex Sakula}

This paper tells the story of the Congress, Baroness Burdett-Coutts, the garden party, the artist, and the painting, which now hangs in the Wellcome Institute for the History of Medicine.

\section{ACKNOWLEDGEMENT}

I wish to thank Mr. William Schupbach, Keeper of Art Collections, Wellcome Institute for the History of Medicine, for his kind co-operation.

\section{APPENDIX}

The following famous names appear among the more than 3,000 Congress members:

British participants included:

Charles Edouard Brown-Séquard (1817-1916)

Sir Thomas Lauder-Brunton (1844-1905)

William Cayley (1836-1916)

John Langdon Haydon Down (1828-1896)

Sir William Henry Flower (1831-1899)

Sir Michael Foster (1836-1907)

Sir Archibald Edward Garrod (1857-1936)

Samuel James Gee (1839-1911)

Arthur Hill Hassall (1817-1894)

Professor Thomas Henry Huxley (1825-1895)

Surgeon-General Professor Thomas Longmore (1816-1895)

Sir Morell McKenzie (1837-1892)

Henry Maudsley (1835-1918)

Sir William Overend Priestley (1829-1900)

Sir William Scovell Savory (1826-1895)

Sir Felix Semon (1849-1921)

Sir John Simon (1816-1904)

Sir Henry Thompson (1820-1904)

Sir Frederick Treves (1853-1923)

Sir William Erasmus Wilson (1809-1884)

Foreign participants included:
Austin Flint (1812-1886)
Moritz Kaposi (1837-1902)
Edwin Klebs (1834-1913)
Robert Koch (1843-1910)
Adolf Küssmaul (1822-1902)
James Marion Sims (1813-1883)
Frederick Trendelenburg (1844-1924)

Some of these distinguished medical men may be portrayed in the painting of Baroness Burdett-Coutts' garden party. The author would be glad to hear from any reader who can help to identify further faces in the painting. 